\title{
Synthesis and Toxicity Test Of Zinc (II) Pyridine-2,6-Dicarboxylate Complexes
}

\author{
Fahimah Martak and Tia Ayu Christanti ${ }^{1}$
}

\begin{abstract}
Complexes of zinc (II) with pyridine-2,6-dicarboxylic acid were synthesized from a reaction between zinc(II) chloride and pyridine-2,6-dicarboxylic acid with two different methods. The first method was carried out by reflux method, mixing a certain mole ratio of metal and ligand in the mixed solution of methanol:water (1:1) as the solvent. The second method was carried out by employing a direct reaction of metal and ligand in a 1:2 mole ratio of the same solvent as it is of the first method. The first method yielded a small clear crystal grains shaped like parallelogram with the molecular formula of [ $\mathrm{Zn}\left(\mathrm{H}_{2}\right.$ dipic,dipic) $\left.\mathrm{Zn}_{2}\left(10 \mathrm{H}_{2} \mathrm{O}\right)\right] \mathrm{Cl}_{4} \cdot 5 \mathrm{H}_{2} \mathrm{O}$ (Complex I-trinuclear). The second method yielded the colorless needle-like crystals and molecular formula $\left[\mathrm{Zn}\left(\mathrm{H}_{2} \text { dipic }\right)_{2} \mathrm{Zn}\left(\mathrm{H}_{2} \mathrm{O}\right)_{5}\right] \mathrm{Cl}_{4} \cdot 2 \mathrm{H}_{2} \mathrm{O}$ (Complex II-dinuclear). Both complex compounds were tested their toxicity using Brine Shrimp Lethality Test (BSLT) method and obtained LC50 values of 989.26 and 503.32 ppm, respectively.
\end{abstract}

Keyword—complex compounds, ligands, metal ion zinc(II), acid pyridine-2,6 dicarboxylic acid, toxicity

\begin{abstract}
Abstrak-Senyawa kompleks Seng(II) dengan asam piridin-2,6-diarboksilat telah disintesis dengan dua metode berbeda. Metode pertama dilakukan dengan metode refluks, mereaksikan larutan logam dan ligan dengan perbandingan mol tertentu dalam pelarut methanol: air (1:1). Metode kedua direaksikan larutan logam dan ligan dengan perbandingan mol 1:2, pelarut yang digunakan sama dengan metode pertama. Kristal jernih berbentuk persegi dengan formula molekul [ $\mathrm{Zn}\left(\mathrm{H}_{2}\right.$ dipic,dipic $\left.) \mathrm{Zn}_{2}\left(10 \mathrm{H}_{2} \mathrm{O}\right)\right] \mathrm{Cl}_{4} \cdot 5 \mathrm{H}_{2} \mathrm{O}$ dihasilkan dari sintesis dengan metode pertama. Kristal seperti jarum dengan formula molekul [ $\left.\mathrm{Zn}\left(\mathrm{H}_{2} \text { dipic }\right)_{2} \mathrm{Zn}\left(\mathrm{H}_{2} \mathrm{O}\right)_{5}\right] \mathrm{Cl}_{4} \cdot 2 \mathrm{H}_{2} \mathrm{O}$ dihasilkan dari sintesis dengan metode kedua. Kedua senyawa kompleks yang dihasilkan diuji toksisitasnya dengan metode Brine Shrimp Lethality Test (BSLT), nilai LC Fo $_{5}$ untuk masing-masing senyawa berturut-turut adalah 989.26 dan 503.32 ppm.
\end{abstract}

Kata kunci-senyawa kompleks, ligand, ion logam Zn(II), asam pyridine-2,6 dikarboksilat, toksisitas

\section{INTRODUCTION}

$\mathrm{P}$ yridine-2,6-dicarboxylic acid (dipicolinate) was first found to have relation with biological systems in 1936 and known as the largest component of the bacterial spores. $\mathrm{H}_{2}$ dipic is used at most as the enzyme inhibitors and plant maintenance. Currently, previous researches on $\mathrm{H}_{2}$ dipic show that the acid contained in it can prevent oxidation process in low density lipoprotein. Pyridine-2,6-dicarboxylic acid which is also one of the carboxylic acid derivatives has interesting coordination chemistry. $\mathrm{H}_{2}$ dipic is also potential to produce various forms of coordination.

Pyridine-2,6-dicarboxylic acid can interact with several metal ions that are owned by human body. One way to determine chemical properties and amino acid in dipicolinate is by investigating them in the form of complex compounds [1], and as in the complex between the $\mathrm{Zn}$ (Zinc) and chitosan is active as an anti-microbial [2]. Zinc, a metal ion which has the electroncon figuration of the $d^{10}$, is a perfect construction of coordination polymers as well as networks (networks).

The metal ion of $d^{10}$ allows a flexible configuration for the formation of complex geometries ranging from trigonal $\mathrm{Zn}$ bipyramidal $\left(s p^{3} d\right)$ and square planar to octahedral $\left(s p^{3} d^{2}\right)$ and many other distortions that may

${ }^{1}$ Fahimah Martak and Tia Ayu Christanti are with Department of Chemistry, FMIPA, Institut Teknologi Sepuluh Nopember, Surabaya, 60111, Indonesia. Email:fahimahm@ chem.its.ac.id. occur [3]. One example of this is the zinc complexes with 1-hydroxypyridine-2-thione in its application that can inhibit prostate cancer cells (A549 lung and PC3) in xenograft models [4].

The structure of the zinc complexes with ligands of dipicolinate has been figured out, but studies on the nature toxicity has still not assessed yet. Therefore, this study attempts to test the toxicity characteristics that would lead to anti-cancer. Then, further assessment of different methods of synthesis are expected to provide different crystal structures.

Toxicity tests of the compound are commonly performed by BSLT (Brine Shrimp Lethality Test). BSLT uses Artemia salina shrimp larvae as tested animals. This method, in addition, is easy, fast and accurate enough, and also frequently used in the searching for new anticancer-research, generally derived from plants. The results of toxicity tests with Brine Shrimp Lethality Test methods have been shown to have a correlation with the power of cytotoksis anticancer compounds. Toxicity test results expressed in percent of the $\mathrm{LC}_{50}$ (Lethal Consentratios) $[5,6]$.

\section{METHOD}

A. Synthesis of Complex I, Zn (II)- pyridine-2,6dicarboxylic acid by reflux method

A total amount of $\mathrm{H}_{2}$ dipic $1.6712(10 \mathrm{mmol})$ was dissolved in a solvent of methanol:water $(1: 1)$ each 25 $\mathrm{mL}$ and then put in a three neck flask. 0.68145 gram $(5$ mmol) of $\mathrm{ZnCl}_{2}$ was sealed into a three neck flask containing $\mathrm{H}_{2}$ dipic solution [7]. Then the mixture was refluxed in the temperature of $70{ }^{\circ} \mathrm{C}$ while stirring at 400 rpm for 3 hours; as soon as the mixture was cooled to 
room temperature, the colorless needle-like crystals were obtained. The obtained crystal was characterized and tested by bioactivity.

\section{B. Synthesis of Complex II, Zn (II)- Pyridine-2, 6 Dicarboxylic Acid using Non-Reflux Method}

A total amount of $\mathrm{H}_{2}$ dipic $1.6712(10 \mathrm{mmol})$ was dissolved in methanol:water (1:1). 0.68145 gram (5 mmol) $\mathrm{ZnCl}_{2}$ was dissolved in water. $\mathrm{ZnCl}_{2}$ solution was stirred at $400 \mathrm{rpm}$ to room temperature, and was added to $\mathrm{H}_{2}$ dipic solution [8]. The mixture was heated at $60{ }^{\circ} \mathrm{C}$ for 24 hours, then it was colled to room temperature; after 5 days, the colorless needle-like crystals were obtained. Crystals was collected on filter and washed with a small amount of water.

\section{Determination of Metal Ion Content}

Solution was prepared by weighing samples of complex I as much as 0.0046 gram, adding two drops of concentrated $\mathrm{HNO}_{3}$ and dissolved in distilled water at 10 $\mathrm{mL}$ volumetric flask. The addition of distilled water to mark boundaries in order to obtain a solution of $100 \mathrm{ppm}$ concentration. Solution was then diluted to obtain a solution with a concentration of $2 \mathrm{ppm}$. The same treatment performed on complex II with a weighing of 0.0056 gram. Final solution with concentration of $2 \mathrm{ppm}$ was then aspirated on the appliance.

\section{Determination of the Content of $C, H$ and $N$}

Elemental analysis for $\mathrm{C}, \mathrm{H}, \mathrm{N}$ were carried out with Perkin Elmer Thermo Finnigan EA 1112 elemental analyser. Elemental analyser was standardized with LCistina Standard $\left(\mathrm{C}_{6} \mathrm{H}_{12} \mathrm{~N}_{2} \mathrm{O}_{4} \mathrm{~S}_{2}, \mathrm{C}=29.99 \%, \mathrm{H}=5.03 \%\right.$, $\mathrm{N}=11.66 \%, \mathrm{~S}=26.69 \%$ and $\mathrm{O}=26.63 \%$ ) before it was used. $2.83 \mathrm{mg}$ was placed in an aluminum foil and sealed in a perforated plate for an oxygen-burning process. Element of micro tool was run and the elemental composition of $\mathrm{C}, \mathrm{H}, \mathrm{N}$ and $\mathrm{S}$ compounds were made legible on computer screen.

\section{E. Determination of Functional Groups by Infrared Spectroscopy}

Functional groups coordinated in the metal ion is were determined by an infrared spectrophotometer. The materials used were in the form of complex solids. Infrared spectra was recorded in $\mathrm{KBr}$ pellet in the range of 4000-300 $\mathrm{cm}^{-1}$ on Shimadzu FTIR Prestige-21 spectrometer.

\section{F. Analysis of Magnetic Moment}

Magnetic moment measurements performed at room temperature were observed by weighing the empty tube and its mass and expressed as an $\mathrm{m}_{\mathrm{o}}$. The next tube was inserted into the tool and the value of magnetic susceptibility (R) that appears recorded as Ro, the next with footage filling the tube. The tubes were weighed again and its mass is expressed as $\mathrm{M}$ and also measured the magnetic susceptibility footage afterwards expressed as $\mathrm{R}_{1}$. Height in the tube and the temperature (in Kelvin) were recorded. Data variable obtained were calculated to obtain magnetic moment.

\section{G. Analysis of ${ }^{1} H$ NMR and ${ }^{13} C N M R$}

${ }^{1} \mathrm{H}$ NMR and ${ }^{13} \mathrm{C}$ NMR were recorded on NMR (JEOL JNM-ECA) $500 \mathrm{Mhz}$ in DMSO- $d_{6}$. The chemical shifts are referred to TMS (the accuracy is $0.01 \mathrm{ppm}$ ).
Measurement of ${ }^{1} \mathrm{H}$ NMR and ${ }^{13} \mathrm{C}$ NMR chemical research was carried out in the center-LIPI. However, before measuring NMR, the test on the solubility of the ligand and the two complexes were performed at 5 different solvents, namely the solvent DMSO, acetone, methanol, chloroform, and $\mathrm{H}_{2} \mathrm{O}$ [9]. Solubility test was performed on a vial of clear bottles, by taking $1 \mathrm{mg}$ of sample with $1 \mathrm{~mL}$ of solvent. Samples were dissolved in a deuterium solvent $\left(\mathrm{D}_{2} \mathrm{O}\right)$, which previously had been determined by solubility, and then inserted into the NMR tube and then analyzed.

\section{H. Electrical Conductivity Analysis}

Standard solution of $\mathrm{KCl}$ and $\mathrm{MgCl}_{2} \cdot 6 \mathrm{H}_{2} \mathrm{O}$ with concentration of $0.001 \mathrm{M}$ was prepared in advance in methanol solvent. Complex I and complex II with concentration of $0.001 \mathrm{M}$ were prepared in the same solvent. Electrical conductivity was measured with conductometer.

\section{Toxicity Test}

Toxicity tests was conducted to determine the $\mathrm{LC}_{50}$ (Lethal Concentration) of $\mathrm{ZnCl}_{2}, \mathrm{H}_{2}$ dipic, complex (I) and complex (II). Concentration of test solutions was made with $62.5 \mathrm{~g} / \mathrm{ml}, 125 \mu \mathrm{g} / \mathrm{ml}, 250 \mu \mathrm{g} / \mathrm{ml}, 500 \mu \mathrm{g} /$ $\mathrm{ml}$ and $1000 \mu \mathrm{g} / \mathrm{ml}$ and then were was taken and put in a $15 \mathrm{~mL}$ tube and then inserted into the tube with a capacity of $30 \mathrm{~mL}$. $15 \mathrm{~mL}$ of sea water was filled with 10 of shrimp pups [10]. The tube was then allowed to stand for 24 hours and then to counted the number of shrimp pups which visually died. The tests were performed three times for each concentration. Artemia salina larvae were said to be died if it did not show any movement during the observation. When there were deaths in the control, it was corrected by Abbot's formula [11].

\section{RESULT AND DISCUSSION}

Prediction of crystal structure I can start with the measurement of zinc levels by AAS instrument (atomic absorption spectroscopy). The method was used to determine the levels of zinc in complex synthesis. These measurements can be supplemented with data from the elemental analyzer elements of $\mathrm{C}, \mathrm{H}$, and $\mathrm{N}$. Measurement of zinc levels in the complex I shows the results of $19.77 \%$. If the results of these measurements are combined with data $\mathrm{C}, \mathrm{H}, \mathrm{N}$ then obtained a complex variety of possible formulas shown in Table 1.

Table 1 shows that the complex with formula of $\left[\mathrm{Zn}\left(\mathrm{H}_{2}\right.\right.$ dipic,dipic $\left.) \mathrm{Zn}_{2}\left(10 \mathrm{H}_{2} \mathrm{O}\right)\right] \cdot 5 \mathrm{H}_{2} \mathrm{O} \cdot \mathrm{Cl}_{4}$ has good content compatibility of $\mathrm{Zn}, \mathrm{C}, \mathrm{H}$ and $\mathrm{N}$ based on the results of theoretical calculations of trinuclear complex with the experimental data.

The results of infrared spectroscopic measurements on the wave number of $4000-300 \mathrm{~cm}^{-1}$ produces a spectrum as shown in Figure 1.

The spectrum shows a broad peak at $3410.15 \mathrm{~cm}^{-1}$ region, corresponding to an $\mathrm{OH}$ group from the ligand bound to the metal and the $\mathrm{OH}$ hydrate water. The next major peak appears at $1635.64 \mathrm{~cm}^{-1}$ corresponding to $\mathrm{C}=$ $\mathrm{O}$ carboxylic group, which originated from the carbonyl of the ligand that binds to the metal. IR spectrum of the other peaks of the complex I found the peak at 416.62 
and $540.07 \mathrm{~cm}^{-1}$ that for each could be identified as the vibrations of $\mathrm{Zn}-\mathrm{N}$ and $\mathrm{Zn}-\mathrm{O}$.

Before employing NMR analysis, the magnetization of the complexes was analyzed in order to prevent the magnetic field affected by the complex compounds, namely paramagnetic and ferromagnetic, in terms of its characterization [12]. Chemical shift data are shown in Table 2.

Table 2 shows that there is a shift for the ligand at 8.35 which is the aromatic shift. Furthermore, for compound $\mathrm{I}$, there is a shift in the region of $8.40 \mathrm{ppm}$. This indicates the complex environment of aromatic $\mathrm{H}$, and a shift when compared with the ligand, is also an indication that the complex is formed [13]. More analysis can actually be supported by the $\mathrm{C}$ environment, but because the ligand ${ }^{13} \mathrm{C}$ analysis is not done, then it can not be compared like any other type of carbon that can be determined by ${ }^{13} \mathrm{CNMR}$. Each of which appears in the shift of 167.7: 146.3: 143.5: 126.7. These shifts can be divided to be $4 \mathrm{C}$ of the dominant environmental group that is $\approx 167, \approx 146, \approx 143$ and $\approx 126$. Each of these shifts can be explained in the Figure 2 . The shift to the environment $1 \approx 167, \approx 146$ for $\mathrm{C} 2$ and $\mathrm{C} 6, \mathrm{C} 3$ and $\mathrm{C} 5 \approx$ 143 and $\approx 128$ for $\mathrm{C} 4$.

Further analysis is the delivery, where delivery is later than the standards that have been made earlier, namely the conducting $\mathrm{KCl}(+1)$ in water at 157.32 and $\mathrm{MgCl}_{2} \cdot 6 \mathrm{H}_{2} \mathrm{O}(+2)$ at $310.02\left(\mathrm{~S} \mathrm{~cm}^{2} \cdot \mathrm{mol}^{-1}\right)$. Complex I has a conductivity of 621.02 , so it can be concluded that the complex has a charge of $4+$. Of the overall characterization performed, it can be suggested that the structure shown in Figure 3.

Table 3 shows that the complex II is almost the same as dinuclear complex, so it can be concluded that this complex is a dinuclear complex.

For the IR spectra of complex II is shown in Figure.4 is not far different from complex I. Wide peak at 3410.15 $\mathrm{cm}^{-1}$ region which also shows that there is an $\mathrm{OH}$ group either as a ligand bound to the $\mathrm{Zn}(\mathrm{II})$ metal ion or $\mathrm{OH}$ from the water hydrates that bound chemically to the complex as the complex I. The peak at $1705.07 \mathrm{~cm}^{-1}$ correspond to $\mathrm{C}=\mathrm{O}$ vibrational states, and for the vibration of $\mathrm{Zn}(\mathrm{II})$ metal ion with $\mathrm{O}$ and $\mathrm{N}$ atoms appeared at $524.64 \mathrm{~cm}^{-1}$ and $455.2 \mathrm{~cm}^{-1}$, respectively [14].

Another test was employed for the NMR of complex II, in which $1 \mathrm{H}$ NMR was also shifted when compared with the ligand The shift of complex II occurred at 8.38 (s) while the ligand occurred at 8:35 (d), it also supports that complex II is formed. 13C NMR shifts occur at 167.1: 146.4: 142, 8, and 127.5; are also almost the same as previous complex I [15].

In accordance with the characterization of the power delivery $(\Lambda \mathrm{m})$ on complex II conductivity of 562.02 $\left(\mathrm{S} . \mathrm{cm}^{2} \cdot \mathrm{mol}^{-1}\right)$, it can also be concluded that this complex has a charge of +4 . Structure characterization was performed; therefore, it may be advisable that the structure is shown in Figure 4.

\section{A.Characterization Of Complex II}

Prediction of the crystal structure of complex II is also similar to previous measurements of zinc which is begun with the instrument data ofAAS and $\mathrm{C}, \mathrm{H}$ and $\mathrm{N}$ of the elemental analyzer. Measurement of zinc levels in the complex II shows the results of $15.94 \%$. Various possible structures are shown in Table 3.

Table 3 shows that the complex is almost the same as dinuclear complex, so it can be concluded that this complex is a dinuclear complex.

\section{B. Toxicity Test}

Characterization of complex (I) and (II) demonstrate the suitability of the complex of zinc (II) pyridine-2,6dicarboxylic acid. Both complexes are expected to have great potential in terms of toxicity. The method used for toxicity testing is BSLT (Brine Shrimp Lethality Test), in which the test will be obtained from the $\mathrm{LC}_{50}$ (Lethal Concentration) [16].

This study uses an experimental design with treatments of giving the concentration of $2000 \mathrm{ppm}, 1000 \mathrm{ppm}, 500$ ppm, $250 \mathrm{ppm}, 125 \mathrm{ppm}$ and $62.5 \mathrm{ppm}$, respectively, of zinc(II) chloride and $\mathrm{H}_{2}$ dipic as negative gram, and complex (I) and complex (II) as positive gram, by the number of repetition of three times (triplo). The value of $\mathrm{LC}_{50}$ is calculated by equation of the $\log$ of concentration with percentage (\%) of shrimp pups mortality [17]. LC $_{50}$ values of each test solution was then calculated. The $\mathrm{LC}_{50}$ values are obtained for $\mathrm{ZnCl}_{2}, \mathrm{H}_{2}$ Dipic, Zinc Complex I and Zinc Complex II are at 29.54 ppm; 263.66 ppm; 989.26 ppm and 503.32 ppm, respectively.

\section{CONCLUSION}

Complex compound (I) $\left[\mathrm{Zn}\left(\mathrm{H}_{2}\right.\right.$ dipic, dipic) $\left.\mathrm{Zn}_{2}\left(10 \mathrm{H}_{2} \mathrm{O}\right)\right] \cdot 5 \mathrm{H}_{2} \mathrm{O} \cdot \mathrm{Cl}_{4}$ and complex (II) [ $\mathrm{Zn}\left(\mathrm{H}_{2}\right.$ dipic) $\left.2 \mathrm{Zn}\left(\mathrm{H}_{2} \mathrm{O}\right)_{5}\right] \cdot 2 \mathrm{H}_{2} \mathrm{O} \cdot \mathrm{Cl}_{4}$ can be synthesized using acid ligands of pyridine-2,6- dicarboxylic acid and zinc(II) metal ion chloride by the method of heating under reflux and with stirring. Finally, the present study has yielded the results of $1 \mathrm{H}$ NMR shift of the ligand to complex the support for complex formation, and LC50 values for complex I is obtained at $989.26 \mathrm{ppm}$ and $503.32 \mathrm{ppm}$ for complex II.

\section{ACKNOWLEDGMENTS}

The present reaserch has granted a financial support from the Directorate General of Higher Education (DIKTI) in Indonesia, 2013. 


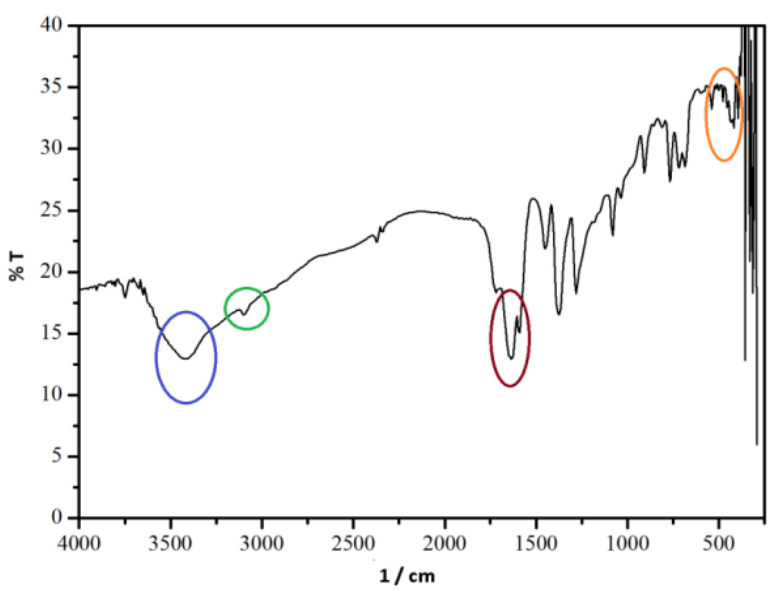

Figure 1. FTIR spectrum of complex I

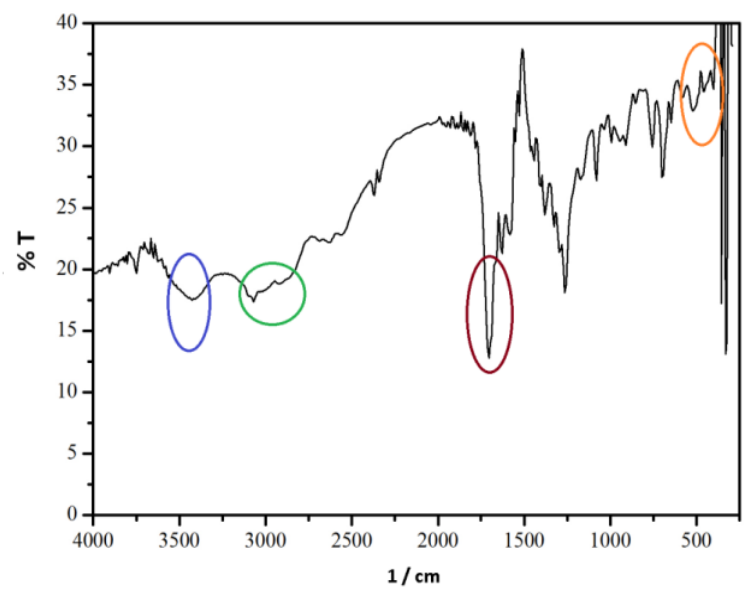

Figure. 3. FTIR spectrum of complex II<smiles>O=C(O)C1CCCC(C(=O)O)N1</smiles>

Figure 2. Prediction of complex structures I and II on the aromatic

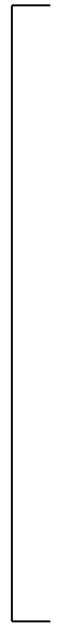

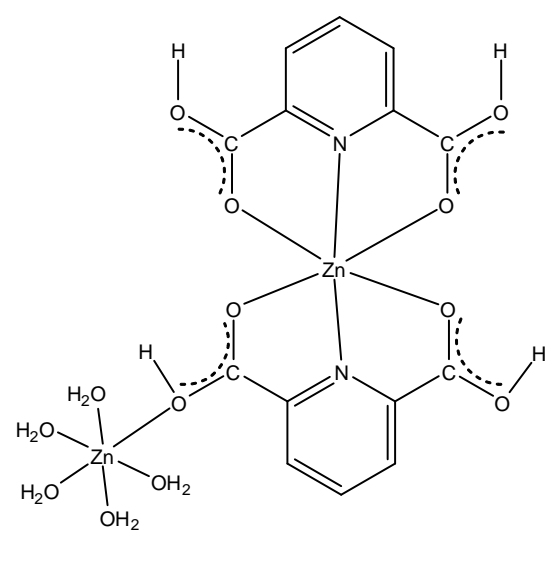

$\mathrm{Cl}_{4} \cdot 2 \mathrm{H}_{2} \mathrm{O}$

TABLE 1.

CONTENT ZN, C, H AND N IN THE COMPLEX I THEORETICALLY AND EXPERIMENT

\begin{tabular}{lcccc}
\hline \multicolumn{1}{c}{ Molecular Formula } & $\% \mathrm{Zn}$ & $\% \mathrm{C}$ & $\% \mathrm{H}$ & $\% \mathrm{~N}$ \\
\multicolumn{1}{c}{ Experiment } & 19.77 & 17.679 & 4.374 & 2.945 \\
\hline $\begin{array}{l}{\left[\mathrm{Zn}(\mathrm{L})_{2} \mathrm{Cl}_{2} \cdot 5 \mathrm{H}_{2} \mathrm{O}\right]} \\
(\text { mononuclear })\end{array}$ & 11.66 & 29.99 & 3.56 & 4.99 \\
$\begin{array}{l}{\left[\mathrm{Zn}(\mathrm{L})_{2} \mathrm{Zn}\left(5 \mathrm{H}_{2} \mathrm{O}\right) \mathrm{Cl}_{4} \cdot 5 \mathrm{H}_{2} \mathrm{O}\right]} \\
(\text { dinuclear })\end{array}$ & 16.60 & 21.36 & 3.81 & 3.56 \\
$\begin{array}{l}{\left[\mathrm{Zn}(\mathrm{L})_{2} / \mathrm{Zn}\right.} \\
(\operatorname{trinuclear})\end{array}$ & 20.86 & 17.88 & 4.04 & 2.98 \\
\hline
\end{tabular}

TABLE 2.

LIGAND NMR DATA, COMPLEX I AND COMPLEX II

\begin{tabular}{cccc}
\hline \multirow{2}{*}{ NMR } & $\begin{array}{c}\mathrm{H}_{2} \text { dipic } \\
(\mathrm{ppm})\end{array}$ & $\begin{array}{c}\text { Complex I } \\
(\mathrm{ppm})\end{array}$ & Complex II (ppm) \\
\hline${ }^{1} \mathrm{H}$ & $8.35(\mathrm{~d})$ & $8.40(\mathrm{~m})$ & $8.38(\mathrm{~s})$ \\
& & 167.7 & 167.1 \\
${ }^{13} \mathrm{C}$ & - & 146.3 & 146.4 \\
& & 143.5 & 142.8 \\
& & 126.7 & 127.5 \\
${ }^{1} \mathrm{H}$ & $8.35(\mathrm{~d})$ & $8.40(\mathrm{~m})$ & $8.38(\mathrm{~s})$ \\
& & 167.7 & 167.1 \\
& & 146.3 & 146.4 \\
${ }^{13} \mathrm{C}$ & - & 143.5 & 142.8 \\
& & 126.7 & 127.5 \\
\hline
\end{tabular}


TABLE 3.

CONTEND ZN, C, H, N IN THE COMPLEX II THEORETICALLY AND EXPERIMENT

\begin{tabular}{ccccc}
\hline \multicolumn{4}{c}{ CONTEND ZN, C, $\mathrm{H}, \mathrm{N}$ IN THE COMPLEX II THEORETICALLY AND EXPERIMENT } \\
\hline Molecular Formula & $\% \mathrm{Zn}$ & $\% \mathrm{C}$ & $\% \mathrm{H}$ & $\% \mathrm{~N}$ \\
\hline $\begin{array}{c}\text { Experiment } \\
{\left[\mathrm{Zn}(\mathrm{L})_{2} \mathrm{Cl}_{2} \cdot 2 \mathrm{H}_{2} \mathrm{O}\right]} \\
(\text { mononuclear })\end{array}$ & 15.94 & 21.457 & 3.689 & 3.983 \\
$\begin{array}{c}\left.\mathrm{Zn}(\mathrm{L})_{2} \mathrm{Zn}\left(5 \mathrm{H}_{2} \mathrm{O}\right) \mathrm{Cl}_{4} \cdot 2 \mathrm{H}_{2} \mathrm{O}\right] \\
(\text { dinuclear })\end{array}$ & 12.90 & 33.18 & 2.76 & 5.53 \\
$\begin{array}{c}\left.\left[\mathrm{Zn}(\mathrm{L})_{2} / \mathrm{Zn}_{2}\left(10 \mathrm{H}_{2} \mathrm{O}\right)\right) \mathrm{Cl}_{4} \cdot 2 \mathrm{H}_{2} \mathrm{O}\right] \\
(\text { trinuclear })\end{array}$ & 17.84 & 22.94 & 3.27 & 3.82 \\
\hline
\end{tabular}

\section{REFERENCES}

1] Z. Vargova, V. Zeleòák, I. Cisaǿvá, and K. Györyová, "Correlation of Thermal and Spectral Properties of Zinc(II) Complexes of Pyridinecarboxylic Acids with Their Crystal Structures". Journal Thermochimica Acta, Vol. 423, pp 149157,2004

[2] L.Wang, D-H. Zhou, and J-P. Zhang, "Catena-Poly [[[bis(2pyridinecarboxylato $\mathrm{N}, \mathrm{O}) \quad$ copper(II)] $\mu$-benzena-1,2,4,5tetracarboxylic acid] dehydrate]", Acta Crystallographica Section E, Vol. 61, pp. 958-960, 2005.

[3] A. Erxlebben, "Structures and properties of Zinc(II) coordination polymers". Journal of coordination Chemistry Review, Vol. 246, pp. 203-228, 2003.

[4] E. Allesio, Bioinorganic Medicinal Chemistry, Wiley-VCH Verlag \& Co. KgaA : Germany, 2011, p. 34.

[5] A.P.D. Nurhayati, N.Abdulgani, and R. Febrianto, "Uji Toksisitas Ekstrak Eucheuma Alvarezil Terhadap Artemia Salina sebagai Studi Pendahuluan Potensi Antikanker", Akta Kimia, Vol. 2, pp. 41-46, 2006.

[6] B.N. Meyer, N.R. Ferrighi, J.E. Putnam, and L.B. Jacobsen, "Brine shrimp: A convenient general bioassay for active plant constituents", Planta Medica, Vol. 45, pp.31-34, 1982.

[7] A.T. Çolak, F. Çolak, and O.Z. Yeşilel, "Büyükgüngör, Synthesis, Structural characterisation of zinc(II)-pyridine-2,5dicarboxylate complexes and self-assembled 1D cluster in a supramolecular architecture", Vol. 8, pp. 85-92, 2009.

[8] A.T. Çolak, F. Çolak, O.Z. Yeşilel, and E. Şahin, "Synthesis, Spectroscopic, Thermal, Crystal Characterization and Biological Activity of $\left\{\left[\mathrm{Ni}(\text { phen })_{3}\right]\left[\mathrm{Ni}(\text { dipic })_{2}\right]\right\}_{2} \cdot 17 \mathrm{H}_{2} \mathrm{O}$ $\left(\mathrm{H}_{2}\right.$ dipic: pyridine-2,6-dicarboxylic Acid, phen:1,10Phenanthroline)", Journal of the Iranian Chemical Society, Vol. 7, pp. 384-393, 2009.

[9] A.T. Çolak, G. Pamuk, O.Z. Yeşilel, and F. Yüksel,
"Hydrothermal synthesis and structural characterization of $\mathrm{Zn}$ (II)-and Cd(II)-pyridine-2,3-dicarboxylate 2D coordination polymers $\left\{\left(\mathrm{NH}_{4}\right)_{2}\left[\mathrm{M}(\mu-\mathrm{pydc})_{2}\right] \cdot 2 \mathrm{H}_{2} \mathrm{O}\right\}_{\mathrm{n}} "$, Journal of Solid State Science, pp. 1-5, 2011.

[10] N.M. Aghatabay, A. Neshat, T. Karabiyik, M. Somer, D Haciu, and B. Dülger, "Synthesis, characterization and antimicrobial activity of $\mathrm{Fe}(\mathrm{II}), \mathrm{Zn}$ (II), $\mathrm{Cd}(\mathrm{II})$ and $\mathrm{Hg}$ (II) complexes with 2,6-bis(benzimidazol-2-yl) pyridine ligand", European Journal of Medicinal Chemistry, Vol. 42, pp.205213, 2006.

[11] B. Setlow, and P. Setlow, Application Environ Microbiology Polyhedron, pp. 59, 640-651, 1993.

[12] K. Håkansson, M. Lindahl, G. Svensson, and J. Albertsson, "The Structure of two solid Zinc Dipicolinatee Complexes", Acta Chemica Scandinavica, Vol. 47, pp.449-455, 1993.

[13] J.C. Dabrowiak, Metals in Medicine, first published, John Wiley \& sons, Ltd, United Kingdom. p.2, 2009.

[14] G.B. Bagihalli, S.A. Patil, and P.S. Badami, "Synthesis, Physicochemical Investigation and Biological Studies of Zinc(II) Complexes with 1,2,4-Triazole Schiff Bases", Journal of the Iranian Chemichal Society, Vol. 6, pp.259-270, 2008.

[15] Y.G. Huang, D. Yuan, Y. Gong, Jiang, L.F., Hong, M., "Synthesis, structure and luminescent properties of lanthanideorganic frameworks based on pyridine-2,6-dicarboxylic acid", Journal of Molecular Structure, Vol. 872, pp. 99-104, 2008.

[16] R.E. Mewis and J. Stephen, "Archibald, Biomedical applications of macrocyclic ligand complexes", Departemen of Chemistry, University of Hull, Cottingham Road, Hull, East Yorkshire HU6 7RX, United Kingdom, Vol. 254, pp.16861712, 2010.

[17] A. Shimizu, L. Nagy, J. Sletten, G. Szalontai, E. Kamu, T. Fiore, L. Pellerito, and E. Kalman, "Preparation and Structura Studies on Dibutyltin(IV) Complexes with Pyridine mono- and dicarboxylic Acids", Journal of Organometallic Chemistry, Vol. 689, pp.1145-1154, 2006. 